\title{
Radionuclide deposition in the Rhône River Prodelta (NW Mediterranean sea) in response to the December 2003 extreme flood
}

\author{
J. Miralles ${ }^{\mathrm{a},{ }^{\star}}, \mathrm{M}$. Arnaudd $^{\mathrm{a},{ }^{, \star}}$, O. Radakovitch ${ }^{\mathrm{b}}$, C. Marion $^{\mathrm{a}}$ and X. Cagnat $^{\mathrm{c}}$
}

\author{
aIRSN, DEI/SESURE/LERCM, Base IFREMER Méditerranée, BP 330, F-83507 La Seyne-sur-Mer \\ cedex, France \\ ${ }^{\mathrm{b}}$ CEREGE, UMR 6635, CNRS/Université Paul Cézanne, BP 80, 13545 Aix-en-Provence cedex, \\ France \\ ${ }^{\mathrm{c}}$ IRSN/DEI/STEME/LMRE, Bois des Rames Bât 501, 91400 Orsay, France \\ *: Corresponding author : imiralles@wanadoo.fr \\ **: Corresponding author : mireille.arnaud@ifremer.fr
}

\begin{abstract}
:
The extreme Rhône River flood that peaked in early December 2003 with water discharges as high as $11,500 \mathrm{~m}^{3} \mathrm{~s}^{-1}$, induced major damage in southern France and transferred large amounts of radionuclides that were associated with suspended particulate matter such as ${ }^{7} \mathrm{Be},{ }^{137} \mathrm{Cs}$ and ${ }^{210} \mathrm{~Pb}$. Specific marine locations in the close vicinity of the Rhône River Mouth were sampled three times in December 2003, February 2004 and April 2004 in order to quantify the consequences of flood events in the Rhône River Prodelta and to investigate the sedimentary depositional patterns through time. The ${ }^{210} \mathrm{~Pb}_{\mathrm{xs}}$ profile analyses in sediment revealed the existence of two particulate matter inputs, one that was related to the December extreme flood and the other to a peak flood of $4000 \mathrm{~m}^{3} \mathrm{~s}^{-1}$ of water discharge that occurred in January 2004. The December event net deposition was assessed at $75 \pm 19 \mathrm{GBq}$ of ${ }^{210} \mathrm{~Pb}_{\mathrm{xs}}$ and $27 \pm 2 \mathrm{GBq}$ of ${ }^{137} \mathrm{Cs}$. The net deposition in response to the January 2004 flood event, although less damaging, is of the same order of magnitude to the December 2003 deposition, i.e. $71 \pm 21 \mathrm{GBq}$ of ${ }^{210} \mathrm{~Pb}_{\mathrm{xs}}$ and $16 \pm 5 \mathrm{GBq}$ of ${ }^{137} \mathrm{Cs}$. The sedimentary records of the December flood exhibited from the cores collected in December 2003, February 2004 and April 2004 are similar arguing for good environmental signal preservation through time but, the standard deviation of flood deposition estimate increases with time after the December flood event indicating a loss of accuracy with time.
\end{abstract}

Keywords: radionuclide deposition; extreme flood; Rhône River Prodelta; Gulf of Lions 


\section{INTRODUCTION}

The Rhône River is known to be the main river of the Western Mediterranean Sea and induces a large transfer of suspended particulate matter and associated radionuclides to the Gulf of Lions and the Western Mediterranean Sea when flood events occur. It is characterized by a 7.6 millions T.yr ${ }^{-1}$ mean solid discharge and a $1700 \mathrm{~m}^{3} \cdot \mathrm{s}^{-1}$ mean water discharge (300-3000 $\mathrm{m}^{3} \cdot \mathrm{s}^{-1}$; Pont et al., 2002) with a large annual variability in response to snow melting or autumn rains that could induce flood events. Such events play a major role in the annual sediment budgets (Walling et al. 1992; Picouet et al., 2001). Indeed, in Mediterranean area, sudden and large floods have a major action on both the sedimentary fluxes and the geomorphological evolution of the river bed (Serrat et al., 2001; Pont et al., 2002); for example, October 1993 flood event, which spent 24 days, delivered 10.7 million tons of suspended particulate matter to the Mediterranean Sea, the 5 days flood of J anuary 1994 drove 6.3 millions tons (Pont, 1997) and the large November-December 2002 flood, 7.6 millions tons i.e. a $88 \%$ of the annual particulate flux (Rolland et al., 2004a). The riverine inputs to the marine systems have been largely studied through marine sediment investigations with some relevant proxy as heavy metals (Ferrand et al., 1999; Bertolotto et al., 2005) or organic matter (Accornero et al., 2003; Miltner et al., 2005). Previous investigations on radionuclides as ${ }^{137} \mathrm{Cs}$ and ${ }^{210} \mathrm{~Pb}$ allowed constraining sedimentary patterns over centennial time scale in agreement with their respective particulate affinity (Zuo et al., 1991; Zuo et al., 1997; Miralles et al., 2005). Unfortunately, Rhône River floods occur at very short time-scales, from day to week that can not be efficiently studied by geochemical tracers such as ${ }^{137} \mathrm{Cs}$ and ${ }^{210} \mathrm{~Pb}$ owing to their respective half-lives. Thus, ${ }^{7} \mathrm{Be}\left(\mathrm{t}_{1 / 2}=53 \mathrm{~d}\right)$ investigations were carried 
out on prodelta sediments in order to evidence the thickness of sediment deposited during the December extreme flood and the induced ${ }^{137} \mathrm{Cs}$ and ${ }^{210} \mathrm{~Pb}_{\mathrm{xs}}$ inventories.

This work presents a characterization of the consequences of the extreme Rhône flood event of December 2003; it deals with the ${ }^{210} \mathrm{~Pb}$ and ${ }^{137} \mathrm{Cs}$ riverine fluxes and sediment inventories determined in the Rhône River Prodelta area and quantifies the retention of radionuclide in prodelta deposits that can act as a secondary source of sediment and contaminants.

\section{SETTINGS}

Rhône Riverdynamics

The Rhône River drains a 98000 km² wide watershed along its $832 \mathrm{~km}$ length in France. South of Arles (50 km from the river mouth), it splits into two main channels, each with a different importance; the eastern arm, Grand Rhône, is 52 km long and encompasses $90 \%$ of the total river water flux while the western arm -Petit Rhône- is $62 \mathrm{~km}$ long and represents the remaining 10\%. The annual average water discharge of the Rhône River is $1700 \mathrm{~m}^{3} . \mathrm{s}^{-1}$ and the annual suspended particulate discharge varies from $110^{6}$ T.yr ${ }^{-1}$ to $26.510^{6} \mathrm{~T} \mathrm{yr}^{-1}$ (Antonelli, 2002). Taking into account the bottom load transport, $77 \%$ to $91 \%$ of the total suspended particulate matter load transit under flood conditions (Pont and Bombled, 1995; Rolland et al., 2004b).

The Rhône River is also a point source for the transfer of artificial radionuclides released by the Marcoule reprocessing plant and the weathering of the watershed contaminated by global fallout that are discharged in the river. Previous studies on radionuclide transfers revealed that $86 \%$ of the ${ }^{137} \mathrm{Cs}$ is bounded on less than $450 \mathrm{~nm}$ particles (Eyrolle and Charmasson, 2004). In 1991, ${ }^{137}$ Cs delivery to the Western Mediterranean Sea was 19.6 Tbq which $40 \%$ were trapped in the prodelta area (Charmasson, 2003). 
Sedimentation conditions at the Rhône River Mouth

The Rhône River discharge is spread over the continental margin by a benthic nepheloid layer system (Aloisi et al., 1982; Monaco et al., 1990) and surperficial plume deflected by external conditions (mainly wind forcing) as shown by numerous modeling studies (Estournel et al., 1997; Marsaleix et al., 1998; Estournel et al., 2001; Ulses et al., 2005).

The Rhône prodelta is a $30 \mathrm{~km}^{2}$ area in the vicinity of the Rhône River mouth extending off the deltaic plain (Aloisi et al., 1975; Boldin et al., 1988; Durrieu de Madron et al., 2000). It is characterized by high organic carbon content (1-2\%), silty mud sedimentation (Durrieu de Madron et al., 2003) and the highest sediment accumulation rates at the margin scale (Miralles et al, 2005).

\section{December 2003 flood episode}

In December 2003, an exceptional flooding episode occurred in the Rhône River, with maximum water discharge reaching $11500 \mathrm{~m}^{3} \cdot \mathrm{s}^{-1}$ on the 3 December at Beaucaire (70 km upstream the river mouth, where the Rhône is still in one channel)

- the highest ever recorded for this river. The recurrence time of such an event is nearly 100 years (Consensus Conference, 2005). The water discharge increased from $2400 \mathrm{~m}^{3} \cdot \mathrm{s}^{-1}$ to $11500 \mathrm{~m}^{3} \cdot \mathrm{s}^{-1}$ in less than 30 hours. The flood was induced by a rainy storm episode across the entire south-eastern region of France caused by the collision between cold air masses and warm humid air masses coming from the Mediterranean Sea. This event was particularly impressive because of its length - it lasted more than 48 hours, instead of the more typical 24-36 hours. In Marseilles, precipitations reached $150 \mathrm{~mm}$ in 24 hours at a time when monthly averages are usually in the order of 50-70 mm. The consequences of this catastrophic flood event included over 500 
$\mathrm{km}^{2}$ of flooded land in the Rhône River low-valley and several deaths. The city of Arles was submerged under 16 millions $\mathrm{m}^{3}$ of floodwater. Here, the water discharge significantly increased from the $1^{\text {st }}$ December to peak at $10000 \mathrm{~m}^{3} \cdot \mathrm{s}^{-1}$ on the $3^{\text {rd }}$ December followed by a steady decrease until the $20^{\text {th }}$ December 2003(fig. 1).

Throughout this period, the water discharge remained in excess of the mean Rhône River water discharge (fig. 1). Suspended matter concentration ([SPM] in mg.l-1) range between 76 mg.l-1 corresponding to the Rhône River off-flood event period suspended load to more than 3600 mg.l-1 at its maximum (Antonelli et al., 2006). Indeed, this flood event induced the transfer of $5.410^{6} \mathrm{~T}$ of suspended particulate matter (SPM) towards the sea during the $1^{\text {st }}$ - $7^{\text {th }}$ December period.

Radionuclides associated to the Rhône River solid discharges delivered to the Gulf of Lions reached $99 \pm 22 \mathrm{Gbq}$ of ${ }^{210} \mathrm{~Pb}_{\mathrm{xs}}$ and $77 \pm 16 \mathrm{Gbq}$ of ${ }^{137} \mathrm{Cs}$ (respectively Rolland et al., 2004b and Antonelli et al., 2006). Out of any flood period, ${ }^{210} \mathrm{~Pb}_{\mathrm{xs}}$ activity associated to the SPM is constant at $60 \mathrm{~Bq} \cdot \mathrm{kg}^{-1}$. It decreased to $20 \mathrm{~Bq} \cdot \mathrm{kg}^{-1}$ when water discharge peaked out on the 3 $3^{\text {rd }}$ December (Eyrolle et al., 2006a; Eyrolle et al., 2006b). The ${ }^{137} \mathrm{Cs}$ content remains constant at $12 \mathrm{~Bq} \cdot \mathrm{kg}^{-1}$ all along the year without flood considerations (Antonelli et al., 2006).

\section{SAMPLING AND METHODS}

Six sediment cores (20-40 cm length) were collected during an EUROSTRATAFORM cruise on the 16 $6^{\text {th }}$ December 2003, just after the extreme December 2003 Rhône River flood. Analyses of specific radionuclides ( ${ }^{7} \mathrm{Be},{ }^{137} \mathrm{Cs},{ }^{210} \mathrm{~Pb}$ ) were performed in order to quantify the particulate flux to Rhône River prodelta in response to specific flow conditions. ${ }^{7} \mathrm{Be}\left(\mathrm{t}_{/ / 2}=53.2 \mathrm{~d}\right)$, a naturally occurring radionuclide resulting from the cosmic ray spallation of nitrogen and carbon in the atmosphere, was analyzed in order to clarify recent particulate deposition (up to 200 d). 'Be reaches the Earth's 
surface bounded on detritical particles and is delivered to marine systems with riverine inputs (Dibb and Rice, 1989; Canuel et al., 1990) depending both on the particulate composition and salinity (Bloom and Crecelius, 1983; Baskaran et al., 1997). Palinkas et al. (2005) showed that the use of ${ }^{7}$ Be to assess flood deposition has to be assessed by sedimentological variable analyses.

${ }^{137} \mathrm{Cs}\left(\mathrm{t}_{1 / 2}=30.1 \mathrm{yrs}\right)$ is an anthropogenically-derived radionuclide. It entered the Environment in response to atmospheric nuclear device tests from 1954 to 1962 that induce a global fallout. Others sources are accidental human releases as Chernobyl accident in April 1986 that have local influences (Anspaugh et al., 1988) and authorized releases from nuclear power plants. In freshwater, ${ }^{137} \mathrm{Cs}$ has a high affinity for the clay (Rogowski et Tamura, 1970) while in seawater, the ion competition generates its releases in dissolved phase. This mechanisms are also responsible of the post depositional mobility of ${ }^{137} \mathrm{Cs}$ in marine sediments (Radakovitch et al., 1999; Frignani et al., 2004). Indeed, ${ }^{137} \mathrm{Cs}$ analyses are justified by its toxicity to the whole Environment.

${ }^{210} \mathrm{~Pb}\left(\mathrm{t}_{\mathrm{y} / 2}=22.3 \mathrm{yrs}\right)$ is a naturally occurring radionuclide produced in the atmosphere by ${ }^{222} \mathrm{Rn}$ decay which binds on submicron atmospheric particles (Gillette et al., 1972). It is deposited onto the Earth'surface by wet and dry deposition processes. Owing to its specific half-life, ${ }^{210} \mathrm{~Pb}$ is useful to assess centennial sedimentation rates in marine systems (Miralles et al., 2005). However, in case of river floods the ${ }^{210} \mathrm{~Pb}$ analysis can be used to evidence any particle depositions in sediments.

Sampling sites were chosen around the River Mouth between $20 \mathrm{~m}$ and about $80 \mathrm{~m}$ depth (fig. 3; table 1). The cores were sub-sampled in $1 \mathrm{~cm}$ thick layers. Each layer was dried, crushed, passed through a $2 \mathrm{~mm}$ sieve and conditioned in $200 \mathrm{ml}$ and 20 $\mathrm{ml}$ geometries for gamma spectrometry investigations. An aliquot is preserved for grain-size feature characterization at LERCM, La Seyne-sur-mer (IRSN, France) on a 
Coulter-Beckman LS 13320 laser grain-sizer. This was not performed on all studied cores but focused on cores we assumed imprinted by flood.

Radionuclides activity are measured part at CEREGE (Centre Européen d’Enseignement et de Recherche des Géosciences de l'Environnement, Université P. Cézanne - CNRS, France) where gamma spectrometry is performed on $20 \mathrm{ml}$ volume geometry samples using a semi-planar intrinsic Germanium detector. The detector is calibrated by counting sediment standards of known activity. The other nondestructive gamma spectrometry are undergone at IRSN Orsay with N-type hyperpurety germanium detectors in $200 \mathrm{ml}$ volume containers and measured with a counting time of 20 or $40 \mathrm{~h}$. Efficiency calibrations from $22.5 \mathrm{keV}$ to $1.8 \mathrm{MeV}$ were carried out using mixed gamma-ray sources in a solid resin-water equivalent matrix of $1.15 \mathrm{~g} . \mathrm{cm}^{-3}$ density. Activity results are corrected for true coincidence summing and self-absorption effects (Lefèvre et al, 2003). ${ }^{7 B}$ Be and ${ }^{137} \mathrm{Cs}$ activities are obtained from the $477.7 \mathrm{Kev}$ and $671 \mathrm{KeV}$ photopeaks respectively. Excess ${ }^{210} \mathrm{~Pb}\left({ }^{210} \mathrm{~Pb}\right.$ xs $)$ activities are determined by subtracting the measured ${ }^{214} \mathrm{~Pb}$ activity ( $352 \mathrm{KeV}$ photopeak) as an indicator of supported ${ }^{210} \mathrm{~Pb}$ to the total ${ }^{210} \mathrm{~Pb}$ peak (46.5 KeV photopeak). The activity uncertainty (at $\mathrm{k}=2$ ) is calculated by standard propagation of calibration source uncertainty, the statistic counting uncertainty (sample and background) and the summing and self-absorption correction uncertainties.

\section{RESULTS AND DISCUSSION}

Flood deposition

Several investigations proved ${ }^{7} \mathrm{Be}$ to be a good tracer of flood deposition in coastal zones (Sommerfield et al., 1999; Mullenbach and Nittrouer, 2000). Nevertheless, Palinkas et al. (2005) evidenced an underestimation of the deposited layer using only ${ }^{7} \mathrm{Be}$ as proxy related to the grain-size changes. In order to assess the relevance of ${ }^{7} \mathrm{Be}$ 
as flood deposition proxy in this work, we determined grain-size changes in each investigated cores. The grain-size distribution (d50) permits to exhibit any changes in deposition conditions and to overview the whole flood consequence for the sediment column.

Among the six prodelta sediment cores, ${ }^{\mathrm{Be}}$ is not detected in BF08 and it is only found in the superficial sediment layer (1 cm depth) in BF13. Regarding the other cores, ${ }^{7 B e}$ was detected at maximum depths ranging from $5 \mathrm{~cm}$ to $18 \mathrm{~m}$ indicating a large variability of sedimentary record for this area (fig. 4; table 2). The core BF05 presents a discontinuous 'Be profile down core with two peak values at $1 \mathrm{~cm}$ and 10 $\mathrm{cm}$ depth while ${ }^{7} \mathrm{Be}$ was still detected at $18 \mathrm{~cm}$ depth. The profile shape could be attributed to mixing processes affecting older material deposited for more than $\sim 200$ days and recently deposited material disturbing the ${ }^{7 B e}$ signal. Other explanation is that high water discharges caused re-suspension of old material stocks deposited onto the Rhône River bed removed by river floods and deposited in the prodelta area, as suggested Thomas (1997). Better understanding could be provided by comparison with ${ }^{234} \mathrm{Th}$ penetration depth. Unfortunately, we did not measure the ${ }^{234} \mathrm{Th}$ activity down core due to his short half life $\left(\mathrm{t}_{1 / 2}=24.1 \mathrm{~d}\right)$. However, comparisons with grain size distribution allows to assess deposition condition changes down cores.

Grain-size distributions are assessed by medium diameter (d50) distribution down core (fig. 5). In core BF05, the d50 baseline is $14 \pm 4 \mu \mathrm{m}$ while it peaks at $65 \mu \mathrm{m}$ at 7 cm depth. Nevertheless, even if this peak can be associated to high energy deposition, it can not be obviously related to the ${ }^{7 B e}$ distribution. The BF05 grain size baseline is higher than other baseline that range from 6 to $9 \mu \mathrm{m}$ (table 3 ) that is synonymous of high energy conditions resulting in coarser material deposition. In core BF06 and $\mathrm{BF} 07, \mathrm{~d} 50$ ranges from about $10 \mu \mathrm{m}$ to $30-40 \mu \mathrm{m}$ with respective baselines of $7 \pm 3 \mu \mathrm{m}$ and $9 \pm 1 \mu \mathrm{m}$ (table 3 ). 
In BF06, where ${ }^{7 B e}$ occurs until $11 \mathrm{~cm}$ depth, d50 increases constantly from $18 \mathrm{~cm}$ depth to the top with a high d50 value (36 $\mu \mathrm{m})$ at $6 \mathrm{~cm}$ depth. In BF07, d50 peaks twice at $1 \mathrm{~cm}$ and $17 \mathrm{~cm}$ depth while ${ }^{7} \mathrm{Be}$ only occurs until $5 \mathrm{~cm}$ depth. We can thus assume that the $17 \mathrm{~cm}$ depth d50 rise is caused by an old flood. The core BF09, where TBe occurs until $9 \mathrm{~cm}$ depth, exhibits a low d50 variability, from $4 \mu \mathrm{m}$ to $19 \mu \mathrm{m}$. The d50 increases from $12 \mathrm{~cm}$ depth to the top with higher d50 in the 0-7 cm depth layer and a $4 \mathrm{~cm}$ depth peak at $19 \mu \mathrm{m}$. Indeed, this argues for a general deposition energy increase. Nevertheless, the grain size increase begins at $12 \mathrm{~cm}$ depth while ${ }^{\mathrm{B}} \mathrm{Be}$ occurs until $9 \mathrm{~cm}$ depth. Thus, the use of $7 \mathrm{Be}$ as unique tracer of flood event is doubtful as evidenced Wheatcroft et al. (2006).

In BF13 core, d50 distribution does not evidenced any drastic energy condition variations with a quite constant shape. This station doesn't seem to be affected by any recent flood events. Recurring investigations on benthic macro fauna at this site showed that Rhône River floods were followed by blooms of opportunistic species taking advantage of recent high organic carbon deposition (Salen-Picard et al., 2003). Nevertheless, this phenomenon was not recorded in December 2003 (C. SalenPicard, Pers. Comm.), demonstrating the weak influence of the flood event at this location. Indeed, the main wind direction was SSE during the November-December period, according to the ALADIN ${ }^{\circledR}$ meteorological modeling studies (C. Estournel, C. Ulses, Pers. Comm.). This experiment shows a general trend of down welling along the coast, caused by elevated surface water levels, and an anticlockwise westward coastal current that pasted the Rhône River plume onto the coast (Marsaleix et al., 1998; Estournel et al., 2001).

Unfortunately, the grain size distribution assessment does not allow neither

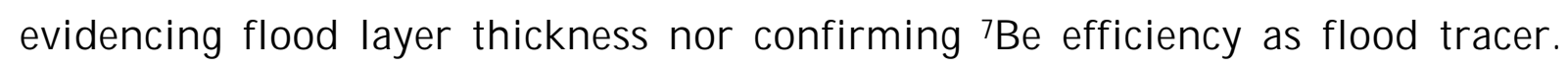


Definitively, we will not use the ${ }^{7} \mathrm{Be}$ as flood layer proxy but as recent particulate matter deposition.

${ }^{210} \mathrm{~Pb}_{\mathrm{xs}}$ and ${ }^{137} \mathrm{Cs}$ vertical distribution and inventories

In cores where ${ }^{7} \mathrm{Be}$ were detected, an obvious feature is the distribution of ${ }^{210} \mathrm{~Pb}_{\mathrm{xs}}$ and ${ }^{137} \mathrm{Cs}$ through the sediment column, despite various emissions patterns in the environment and biogeochemical behaviors (fig. 6). While ${ }^{137} \mathrm{Cs}$ post-depositional mobility has been proven in marine sediments (Radakovitch et al., 1999; Frignani et al., 2004), ${ }^{210} \mathrm{~Pb}$ is not labile once bound to a particle and deposited onto the seafloor. Thus, the extension of the ${ }^{210} \mathrm{~Pb}_{\mathrm{xs}}$ profile all over the cores suggests a large particulate flux episode. The ${ }^{210} \mathrm{~Pb}_{\mathrm{xs}}$ profiles do not exhibit clear radioactive decay trends preventing any attempt of geochronology assessment.

${ }^{7} \mathrm{Be}$ and ${ }^{210} \mathrm{~Pb}_{\mathrm{xs}}$ have similar geochemical behaviors in sediments but their respective half-lives vary from several orders of magnitude, from day to year. Despite these respective features, both radionuclide are detected at similar depths in sediments. This argues to a sediment signal forcing by grain size.

The ${ }^{210} \mathrm{~Pb}_{\mathrm{xs}}$ activity distributions exhibit specific sediment layers characterized by an activity drastic decrease upwards. These decreases are assumed to be dilution phenomena in response to large particulate matter supply (Dominik et al., 1987; Miralles et al., 2004). We assume that the beginning of the decrease in surface layers is related to the onset of a flood, and that the minimum radionuclide activity value marks the maximum flood solid discharge or the flood peak; indeed, for both cores $\mathrm{BF} 05$ and BF 06 the ${ }^{210} \mathrm{~Pb}_{\mathrm{xs}}$ activity decreases from $60 \mathrm{~Bq} \cdot \mathrm{kg}^{-1}$ (at $18 \mathrm{~cm}$ and $6 \mathrm{~cm}$ depth respectively) to less than 20 Bq.kg- ${ }^{-1}$ at $5 \mathrm{~cm}$ and $2 \mathrm{~cm}$ depth. For cores BF 07 and $\mathrm{BF} 09$, the ${ }^{210} \mathrm{~Pb}_{\mathrm{xs}}$ activity decreases from $60 \mathrm{~Bq} \cdot \mathrm{kg}^{-1}$ (at $5 \mathrm{~cm}$ and $2 \mathrm{~cm}$ depth respectively) to close to $40 \mathrm{~Bq} \cdot \mathrm{kg}^{1}$ at the surface. Therefore, ${ }^{210} \mathrm{~Pb}_{\mathrm{xs}}$ activities 
measured in cores BF 05 and BF 06 are in agreement with activities associated to suspended particulate matter measured in the Rhône River at Arles (Rolland et al., submitted). Thus, we assume these cores strongly imprinted by flood deposition. In cores $\mathrm{BF} 07$ and $\mathrm{BF} 09$, the lower ${ }^{210} \mathrm{~Pb}_{\mathrm{xs}}$ activity values assumed to label the day of maximum water discharges are still higher than 20 Bq.kg-1, typical of riverine SPM during high water discharge periods, that relates to a weaker dilution process and may not reflect the flood event with accuracy. However, it is difficult to accurately determine the outcome of a flood on a radionuclide profile and the induced radionuclide inventory; hence, we decided to assess the flood deposition into a large range defined by two assumptions: low or high deposition.

The low deposition assumption considers radionuclide deposition occurs from the flood start to the flood peak - i.e. low activity value, while the "high deposition scenario" assumes a deposition which begins with the flood and ends when ${ }^{210} \mathrm{~Pb}_{\mathrm{xs}}$ activity reaches the values of ${ }^{210} \mathrm{~Pb}_{\mathrm{xs}}$ associated to the SPM transfer in the Rhône River (60 Bq.kg ${ }^{-1}$ ). When several layers of dilution phenomena exist in a sediment core, the deeper sequence layer is, the older flood event like in cores BF 06 and BF 09 (fig. 6; table 4). Indeed, the deeper dilution features, whose lower ${ }^{210} \mathrm{~Pb}_{\mathrm{xs}}$ values at 13 $\mathrm{cm}$ and $12 \mathrm{~cm}$ depth respectively, are expected to correspond to the November 2002 flood. The thicknesses of the layers that correlate to dilution processes vary between $18 \mathrm{~cm}$ in core BF 05 to $3 \mathrm{~cm}$ in the BF 09 core (fig. 6; table 4). The corresponding ${ }^{210} \mathrm{~Pb}_{\mathrm{xs}}$ inventories vary between $1370 \pm 192 \mathrm{~Bq} \cdot \mathrm{m}^{-2}$ and $4625 \pm 393 \mathrm{~Bq} \cdot \mathrm{m}^{-2}$, and ${ }^{137} \mathrm{Cs}$ inventories between $462 \pm 19$ Bq. $\mathrm{m}^{-2}$ and 1890 \pm 40 Bq. $\mathrm{m}^{-2}$. Nevertheless, the core BF 09 shows a ${ }^{210} \mathrm{~Pb}_{\mathrm{xs}}$ shape of decreasing radionuclide activity layer from a depth of 3 $\mathrm{cm}$ to the sediment surface, but lacks the expected inflexion point to mark the flood peak. Thus, the flood deposition scenario cannot be determined from this core: consequently, the ${ }^{210} \mathrm{~Pb}_{\mathrm{xs}}$ and ${ }^{137} \mathrm{Cs}$ inventories were partial inventories that were not 
taken into account in the mean flood deposition inventories estimate in this area. Taking this into account, mean ${ }^{210} \mathrm{~Pb}_{\mathrm{xs}}$ and ${ }^{137} \mathrm{Cs}$ inventories corresponding to the December flood event are estimated to be $2518 \pm 628$ Bq. $\mathrm{m}^{-2}$ and $893 \pm 62$ Bq. $\mathrm{m}^{-2}$ respectively. At the prodelta scale $\left(30 \mathrm{~km}^{2}\right)$, these inventories correspond to the deposition of $75 \pm 19 \mathrm{GBq}$ of ${ }^{210} \mathrm{~Pb}$ and $27 \pm 2 \mathrm{GBq}$ of ${ }^{137} \mathrm{Cs}$, or, respectively, $76 \%$ of the total ${ }^{210} \mathrm{~Pb}_{\mathrm{xs}}$ particulate flux and $35 \%$ of the total ${ }^{137} \mathrm{Cs}$ particulate flux measured in the Rhône River (Antonelli et al., 2006). This is in agreement with the estimate of the ${ }^{137}$ Cs trapped in sediments of the Rhône River Prodelta area determined by Charmasson (2003), i.e. 40 \% related to the prodelta sediment high clay content (e.g. Durrieu de Madron et al., 2000).

Temporal variations of sediment deposition rates

In order to assess changes in the sedimentation patterns through time, core samples were collected at site BF05 three times, in December 2003, February 2004 and April 2004, both ${ }^{137} \mathrm{Cs}$ and ${ }^{210} \mathrm{~Pb}_{\mathrm{xs}}$ activities were measured (fig. 7). The dilution features related to the December 2003 flood are present in each samples at various depths. In the December 2003 core the dilution feature corresponding to the flood is located between 5 to $18 \mathrm{~cm}$ depth. The same feature is found between 10 to $18 \mathrm{~cm}$ depth in the February 2004 core and between 18 to $25 \mathrm{~cm}$ depth in the April 2004 core. From December 2003 to February 2004, the imprint of the December 2003 flood was progressively buried by $5 \mathrm{~cm}$ over this two month-period for a $2.5 \mathrm{~cm}$.month-1 sediment accumulation rate. Instead of actual deepening of the dilution feature between December 2003 and February 2004, it is probably more accurate to suggest compaction as a primary mechanism creating this feature, since the decrease of the ${ }^{210} \mathrm{~Pb}_{\mathrm{xs}}$ activity is $13 \mathrm{~cm}$ long in the December 2003 core and $8 \mathrm{~cm}$ in the February 2004 core. Furthermore, a new dilution feature appears in the February 2004 core 
between 2 and $6 \mathrm{~cm}$ depth that can be related to the increase of the Rhône River water discharges up to $4000 \mathrm{~m}^{3} \cdot \mathrm{s}^{-1}$ in J anuary 2004; this event is also evident in the April $2004{ }^{210} \mathrm{~Pb}_{\mathrm{xs}}$ shape between $5 \mathrm{~cm}$ and $9 \mathrm{~cm}$ depth, deepened by $3 \mathrm{~cm}$ over a two month-period implying an apparent sediment accumulation rate of $1.5 \mathrm{~cm} . \mathrm{month}^{-1}$, i.e. 2 orders of magnitude higher than the centennial sediment accumulation rates measured by ${ }^{210} \mathrm{~Pb}_{\mathrm{xs}}$ method (Miralles et al., 2005).

Time evolution of radionuclide inventories

The estimated ${ }^{210} \mathrm{~Pb}_{\mathrm{xs}}$ and ${ }^{137} \mathrm{Cs}$ low and high inventories for the February 2004 and April 2004 cores were determined according to the same assumptions as the December 2003 inventories (table 5). The estimated mean ${ }^{210} \mathrm{~Pb}_{\mathrm{xs}}$ inventories in sediments are similar in the December 2003, February 2004 and April 2004 cores: they range between $4275 \pm 495$ Bq. ${ }^{-2}$ in the December 2003 core to $2897 \pm 1488$ Bq. $\mathrm{m}^{-2}$ in the April 2004 core. The mean ${ }^{137} \mathrm{Cs}$ inventories are also similar through time: they range from $1631 \pm 366$ Bq. $\mathrm{m}^{-2}$ in the December 2003 core to $1110 \pm 526$ Bq. $\mathrm{m}^{-2}$ in the April 2004 core. ${ }^{210} \mathrm{~Pb}_{\mathrm{xs}}$ distribution in these cores revealed a dilution feature in the first centimeters of the February 2004 and April 2004 cores. These are probably related to a water discharge increase that occurred in J anuary 2004, with maximum value reaching $4000 \mathrm{~m}^{3} \cdot \mathrm{s}^{-1}$ in Arles (fig. 7). Induced ${ }^{210} \mathrm{~Pb}_{\mathrm{xs}}$ and ${ }^{137} \mathrm{Cs}$ deposition are estimates at $2375 \pm 713$ Bq. $\mathrm{m}^{-2}$ and $537 \pm 153 \mathrm{~Bq} \cdot \mathrm{m}^{-2}$ in the February 2004 core, or $71+21 \mathrm{GBq}$ of ${ }^{210} \mathrm{~Pb}_{\mathrm{xs}}$ and $16 \pm 5 \mathrm{GBq}$ of ${ }^{137} \mathrm{Cs}$ at the prodelta scale, similar to the extreme December 2003 flood net deposition (table 4). In fact, maximum water discharge value was lower than the December 2003 peak but remained high for a longer time period (one day higher than $3000 \mathrm{~m}^{3} \cdot \mathrm{s}^{-1}$ in December 2003 and about one week in J anuary 2004). 


\section{CONCLUSIONS}

The December 2003 Rhône River flood, which peaked on 3. December, was an extreme event characterized by water discharges that reached $11500 \mathrm{~m}^{3} \cdot \mathrm{s}^{-1}$ in Beaucaire (70 Km upstream) and about $10000 \mathrm{~m}^{3} . \mathrm{s}^{-1}$ in Arles, where flood damages were substantial. Despite high difficulty to define the flood layer, the assumption of two various deposition scenarios allowed us to determine the range of flood particulate deposition. Radionuclide depositions related to this event are $75 \pm 19 \mathrm{GBq}$ of ${ }^{210} \mathrm{~Pb}_{\mathrm{xs}}$ and $27 \pm 2 \mathrm{GBq}$ of ${ }^{137} \mathrm{Cs}$, about $76 \%$ and $35 \%$ of the annual radionuclide Rhône River budget.

The comparison between sedimentary radionuclide inventories in cores collected at different 2-month lap time (December 2003, February 2004 and April 2004) showed that the flood record $\left({ }^{137} \mathrm{Cs}\right.$ and ${ }^{210} \mathrm{~Pb}_{\mathrm{xs}}$ inventories) did not change with time. However, the standard deviation increased with time and reduced the accuracy of the radionuclide particulate flux estimates.

These investigations also allowed quantification of particulate flux inputs related to an increase of the Rhône River water discharges in J anuary (up to $4000 \mathrm{~m}^{3} \cdot \mathrm{s}^{-1}$ ), which induced a net deposition of ${ }^{210} \mathrm{~Pb}_{\mathrm{xs}}$ and ${ }^{137} \mathrm{Cs}$ in a same order of magnitude as the extreme December 2003 flood. We emphasize that prodelta sediment can be used as a relevant proxy of the riverine short time-scale events.

Nevertheless, it has to be taken into account that these estimates of Rhône River flood event were based on a too few number of sediment cores to hope accurately defined the sedimentary dynamics in such extreme condition at the whole prodelta scale. Improvements have still to be done on mapping of the flood layer off shore to accurately assess the response of the Continent-Ocean transitional area when Rhône River extreme events occur. 


\section{Acknowledgements}

This study was supported by the European project EUROSTRATAFORM (Number EVK3-CT-2002-00079) and IRSN research program. The authors thank the crews aboard the N/O Suroît (IFREMER), N/O Antedon II (INSU), and N/O Téthys II (INSU) and Serge Berné for December 2003 cruise organization. The authors thank the CNR (Compagnie Nationale du Rhône) for the Rhône River discharge data. Authors would also thank the reviewers that contributed to improve the quality of this manuscript.

\section{References}

Accornero, A., Picon, P., Debovée, F., Charrière, B., Buscail, R., 2003. Organic carbon budget at the sediment-water interface on the Gulf of Lions continental margin. Cont. Shelf Res. 23, 79-92.

Aloisi, J-C., Cambon, J-P., Carbonne, J ., Cauwet, G., Millot, C., Monaco, A., 1982. Origine et rôle du néphéloïde profond dans le transfert des particules au milieu marin. Application au Golfe du lion. Oceanol. Acta 5, 481-491.

Aloisi, J -C., Monaco, A., Pauc, H., 1975. Mécanismes de la formation des Prodeltas dans le Golfe du Lion. Exemple de l'embouchure de l'Aude (Languedoc). Bull. Geol. Bassin Aquitaine 18, 3-12.

Anspaugh, L. R., Catlin, R. J ., Goldman, M., 1988. The global impact of the Chernobyl accident. Science 242, 1513-1519.

Antonelli, C., 2002. Flux sédimentaires et morphogenèse récente dans le chenal du Rhône aval. PhD Thesis, Université de Provence, AIX-MARSEILLE, 279 pp.

Antonelli, C., Eyrolle, F., Rolland, B., Arnaud, M., Provansal, M., Sabatier F., 2006. Suspended sediment and artificial radionuclide fluxes during the exceptional floods. Case study: the Rhône River (SE France) in December 2003. Geomorphology. 
Baskaran, M., Ravichandran, M., Bianchi, T. S., 1997. Cycling of ${ }^{7} B e$ and ${ }^{210} \mathrm{~Pb}$ in a high DOC, shallow, turbid estuary of south-east Texas. Estuarine, Coastal Shelf Sci. 45, 165- 176.

Bertolotto, R. M., Tortarolo, B., Frignani, M., Bellucci, L. G., Albanese, S., Cuneo, C., Alvarado-Aguilar, D., Picca, M. D., Gollo, E., 2005. Heavy metals in surficial coastal sediments of the Ligurian Sea. Mar. Poll. Bull. 503, 348-356.

Bloom, W. M., Crecelius, E. A., 1983. Solubility behaviour of atmospheric ${ }^{7}$ Be in marine environnement. Mar. Chem. 12, 323-331.

Boldin, A., Bortoluzzi, G., Frascani, F., Guerzoni, S., Rabitti, S., 1988. Recent deposits and suspended sediments off the Po della Pila (Po River, main mouth), Italy. Mar. Geol. 79, 159-170.

Canuel, E. A., Martens, C. S., Benninger, L. K., 1990. Seasonal variations in 7Be activity in the sediments of Cape Lookout Bight, North Carolina. Geochim. Cosmochim. Acta 54, 237-245.

Charmasson, S., 2003. ${ }^{137 C s}$ inventory in sediment near the Rhône mouth: role played by different sources. Oceanol. Acta 26, 435-441.

Consensus Conference, 2005. Peak discharge of the December 2003 Rhône River flood at Beaucaire. Préfet of the Rhône Mediterranean Watershed - Ministry for Ecology and Sustainable Development, Final Report, 14 pp.

Dibb, J . E., Rice, D. L., 1989. Temporal and spatial distribution of Beryllium-7 in the sediments of Chesapeake Bay. Estuarine Coastal Shelf Sci. 28, 395-406.

Dominik, J., Burrus, D., Vernet, J. P., 1987. Transport of the environmental radionuclides in an Alpine watershed. Earth Planet. Sci. Let. 84, 165-180.

Durrieu de Madron, X., Abassi, A., Heussner, S., Monaco, A., Aloisi, J-C., Radakovitch, O.,Giresse, P., Buscail, R., Kerhervé, P., 2000. Particulate matter and 
organic carbon budgets for the Gulf of Lions (NW Mediterranean). Oceanol. Acta 23, 717-723.

Durrieu de Madron, X., Denis, L., Diaz, F., Garcia, N., Guieu, C., Loÿe-Pilot, M-D., Ludwig, W., Moutier, T., Raimbault, P., Ridame, C., 2003. Nutrients and carbon budgets for the Gulf of Lions during the MOOGLI cruises. Oceanol. Acta 26, 421-433. Estournel, C., Broche, P., Marsaleix, P., Devenon. J-L., Auclair, F., Vehil, R., 2001. The Rhône River Plume in Unsteady Conditions: Numerical and Experimental Results. Estuarine Coastal Shelf Sci. 53, 25-38.

Estournel, C., Kondrachoff, V., Marsaleix, P., Vehil, R., 1997. The plume of the Rhône: numerical simulation and remote sensing. Cont. Shelf Res. 17, 899-924.

Eyrolle, F., Charmasson, S., 2004. Plutonium isotopes in the lower reaches of the River Rhône over the period 1945- 2000: fluxes towards the Mediterranean Sea and sedimentary inventories. J Environ. Radioactivity 174, 127-138.

Eyrolle, F., Duffa, C., Antonelli, C., Rolland, B., Leprieur, F., 2006a. Radiological consequences of the extreme flooding on the lower course of the Rhône Valley (December 2003, South East France). Sci. Tot. Env. 366, 427-438.

Eyrolle, F., Rolland, B., Antonelli, C., Metivier, J .-M., 2006b. Artificial radioactivity within the Rhône River waters. Consequence of flood on activity levels and fluxes toward the sea. Environnement, Risques et Santé 5, 83-92.

Ferrand, J-L., Hamelin, B., Monaco, A., 1999. Isotopic tracing of anthropogenic $\mathrm{Pb}$ inventories and sedimentary fluxes in the Gulf of Lions (NW Mediterranean). Cont. Shelf Res. 19, 23-47.

Frignani, M., Sorgente, D., Langone, L., Albertazzi, S., Ravaioli, M., 2004. Behaviour of Chernobyl radiocesium in sediments of the Adriatic Sea off the Po River delta and the Emilia-Romagna coast. J . Environ. Radioactivity 71, 299-312. 
Gillette, D. A., Blifford, I. H., Fenster, C. R., 1972. Measurements of the aerosols size distribution and vertical fluxes of aerosols on land subject to wind erosion. J . Applied Meteorology 11, 977-987.

Lefèvre O., Bouisset P., Germain P., Barker E., Kerlau G., Cagnat X., 2003. Selfabsorption correction factor applied to 129I measurement by direct gamma-X spectrometry for Fucus serratus samples. Nucl. Inst. \& Meth. In phys Res. A506 (2003) 173-185.

Marsaleix, P., Estournel, C., Kondrachoff, V., Vehil, R., 1998. A numerical study of the formation of the Rhône River plume. J . Mar. Syst. 14, 99-115.

Miltner, A., Emeis K-C., Struck, U., Leipe, T., Voss, M., 2005. Terrigenous organic matter in Holocene sediments from the Central Baltic Sea, NW Europe. Chem. Geol. 216, 313-328.

Miralles, J., Radakovitch, O., Aloisi J-C., 2005. ${ }^{210} \mathrm{~Pb}$ sedimentation rates from the Northwestern Mediterranean margin. Mar. Geol. 216, 155-167.

Miralles, J ., Radakovitch, O., Cochran. J. K., Véron, A., Masque, P., 2004. Multitracer study of anthropogenic contamination records in the Camargue, Southern France. Sci. Tot. Env. 320, 63-72.

Monaco, A., Biscaye, P., Soyer, P., Pocklington, R., Heussner, S., 1990. Particle fluxes and ecosystem response on a continental margin: the 1985-1988 Mediterranean ECOMARGE experiment. Cont. Shelf Res. 10, 805-839.

Mullenbach, B. L., Nittrouer, C. A., Puig P. and Orange D.L., 2004. Sediment deposition in a modern submarine canyon : Eel Canyon, Northern California, Marine Geology, 211,1-2,101-119.

Palinkas, C. M., Nittrouer, C. A., Wheatcroft, R. A., Langone, L., 2005. The use of 7Be to identify event and seasonal sedimentation near the Po River delta, Adriatic Sea. Mar. Geol. 222-223, 95-112. 
Picouet, C., Hingray, B., Olivry, J. C., 2001. Empirical and conceptual modelling of the suspended sediment dynamics in a large tropical African river: the Upper Niger River basin. J. Hydrol. 250, 19-39.

Pont, D., 1997. Les débits solides du Rhône à proximité de son embouchure : données récentes (1994-1995). Revue de Géographie de Lyon 72, 1, 23-43.

Pont, D., Bombled, B., 1995. Les débits solides du Rhône à proximité de son embouchure durant l'année hydrologique 1994-1995. 7eme Rencontre de l'Agence Régionale pour l'Environnement, 24-30 octobre 2004, Digne-les-bains, France, 282292.

Pont, D., Simonnet, J-P. , Walter, A. V., 2002. Medium-term changes in suspended sediment delivery to the ocean: consequences of catchment heterogeneity and river management (Rhône River, France). Estuarine Coastal Shelf Sci. 54, 1-18.

Radakovitch, O., Charmasson, S., Arnaud, M., Bouisset, P., 1999. ${ }^{210} \mathrm{~Pb}$ and caesium accumulation in the Rhône Delta sediments. Estuarine Coastal Shelf Sci. 48, 77-92.

Rogowski, A S., Tamura, T., 1970. Environmental mobility of Cesium-137. Radiation Botany 10, 35-45.

Rolland B., Antonelli C., Eyrolle F., 2004a. Fluxes of suspended material and associated radionuclides to the sea during flood events of the Rhône River. ECORAD, September 2004, 6 th-10 $^{\text {th }}$, Aix-en-Provence, France, P3, 35.

Rolland, B., Eyrolle, F., Bourles, D., 2004b. , Removal of Sedimentary Stocks and associated radioactivity in the lower Rhône River (South Eastern France) International Conference on Isotopes in Environmental Studies-Aquatic forum, Monte Carlo, Monaco, 25-29 October 2004, 301-302.

Salen-Picard, C., Arlhac, D., Alliot, E., 2003. Responses of a Mediterranean soft bottom community to short-term (1993-1996) hydrological changes in the Rhône River. Mar. Environ. Res. 55, 409-427. 
Serrat, P., Ludwig, W., Navarro, B., Blazi, J-L., 2001. Variabilité spatio-temporelle des flux de matière en suspension d'un fleuve côtier méditerranéen: la Têt (France). C. R. Acad. Sci. II A, 389-397.

Sommerfield, C. K., Nittrouer, C. A., Alexander, C. R., 1999. Be as a tracer of flood sedimentation on the northern California continental margin. Cont. Shelf Res. 19, 335-361.

Thomas, A. J., 1997. Input of artificial radionuclides to the Gulf of Lions and tracing the Rhône influence in marine surface sediments. Deep Sea Res. II 44, 577-595.

Ulses, C., Grenz, C., Marsaleix, P., Schaaff, E., Estournel, C., Meulé, S., Pinazo, C., 2005. Circulation in a semi-enclosed bay under influence of strong freshwater input. J. Mar. Syst.,56, 113-132.

Walling, D. D., Webb, D. W., Woodward, J. C., 1992. Some sampling considerations in the design of effective strategies for monitoring sediment - associated transport. IAHS Publi. 20, 279-288.

Wheatcroft, R. A., Hunt, L. M., Stevens, A., Lewis, R, 2006 The distribution and internal geometry of the October 2000 Pô River flood deposit: digital x-radiographic evidence. Cont. Shelf Res. 26, 499-516.

Zuo, Z., Eisma, D., Berger, G. W., 1991. Determination of sediment accumulation and mixing rates in the Gulf of Lions, Mediterranean Sea. Oceanol. Acta 14, 253-262.

Zuo, Z., Eisma, D., Gieles, R., Besks, J., 1997. Accumulation rates and sediment deposition in the Northwestern Mediterranean. Deep Sea Res. II 44, 597-609. 
Figure captions

Figure 1: Rhône River water discharges $\left(\mathrm{m}^{3} . \mathrm{s}^{-1}\right)$ measured at Arles (50 km upstream the river mouth) during the 01/01/2001-01/ 03/ 2004 period.

Figure 2: Rhône River water discharges $\left(\mathrm{m}^{3} \cdot \mathrm{s}^{-1}\right)$ and associated suspended particulate matter concentration ([SPM] in mg.l-1) in Arles (from Antonelli et al., 2006).

Figure 3: Sampling sites in the close vicinity of the Rhône River Mouth.

Figure 4: ${ }^{7}$ Be activity (Bq.kg ${ }^{-1}$ dry weight) in cores collected in December 2003.

Figure 5: Medium diameter d50 $(\mu \mathrm{m})$ distribution in cores collected in December 2003.

Figure 6: ${ }^{210} \mathrm{~Pb}_{\mathrm{xs}}$ and ${ }^{137} \mathrm{Cs}$ activities (Bq.kg ${ }^{1}$ dry weight) distribution in sediment cores where $\mathrm{B} B$ analyses exhibited recent particulate deposition. Error bars correspond to $\pm 2 \mathrm{~s} .{ }^{137} \mathrm{Cs}$ activity error bars are included in the point.

Figure 7: ${ }^{210} \mathrm{~Pb}_{\mathrm{xs}}$ and ${ }^{137} \mathrm{Cs}$ activities (Bq.kg-1 dry weight) at BF05 sampling site (a) in December 2003, (b) February 2004 and (c) April 2004. Error bars correspond to \pm 2 s. ${ }^{137} \mathrm{Cs}$ activity error bars are included in the point. 


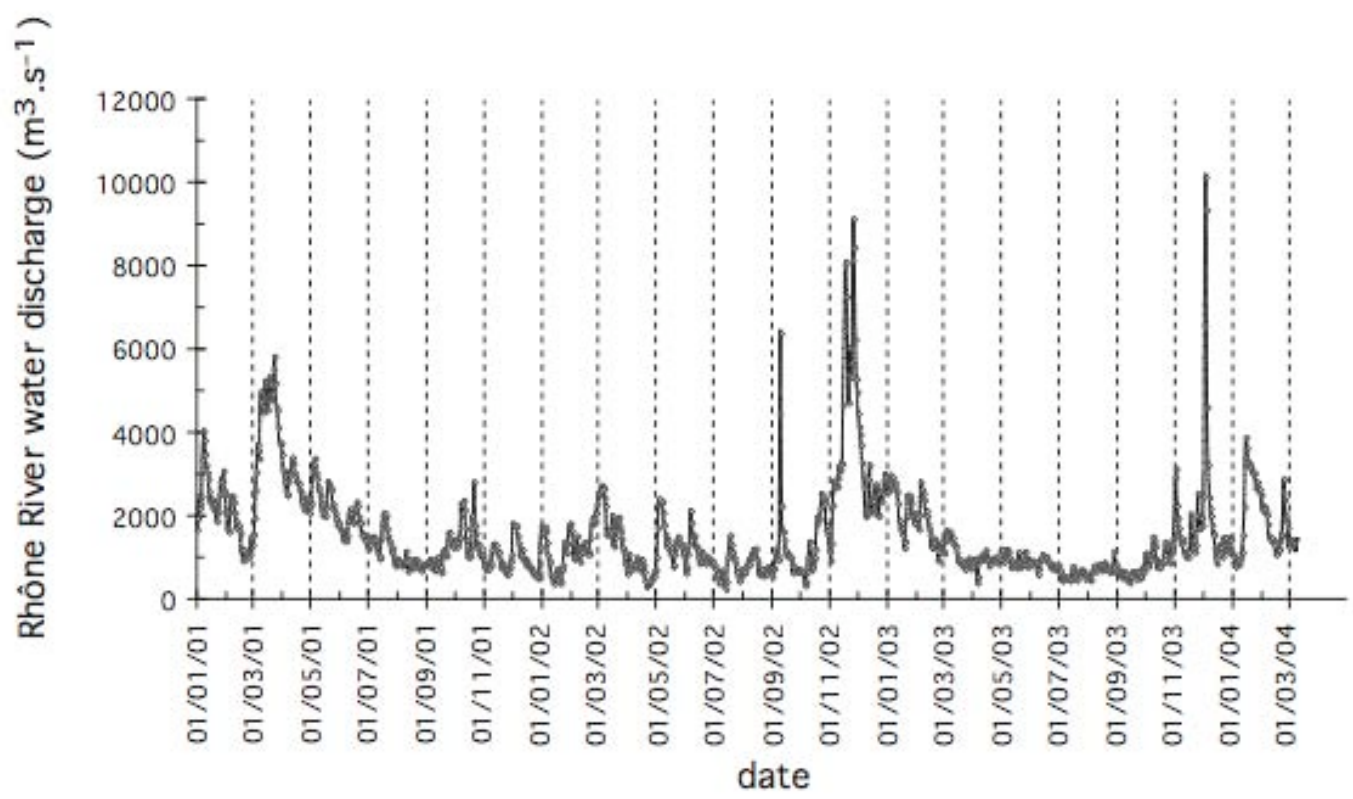

Figure 1: Miralles et al.

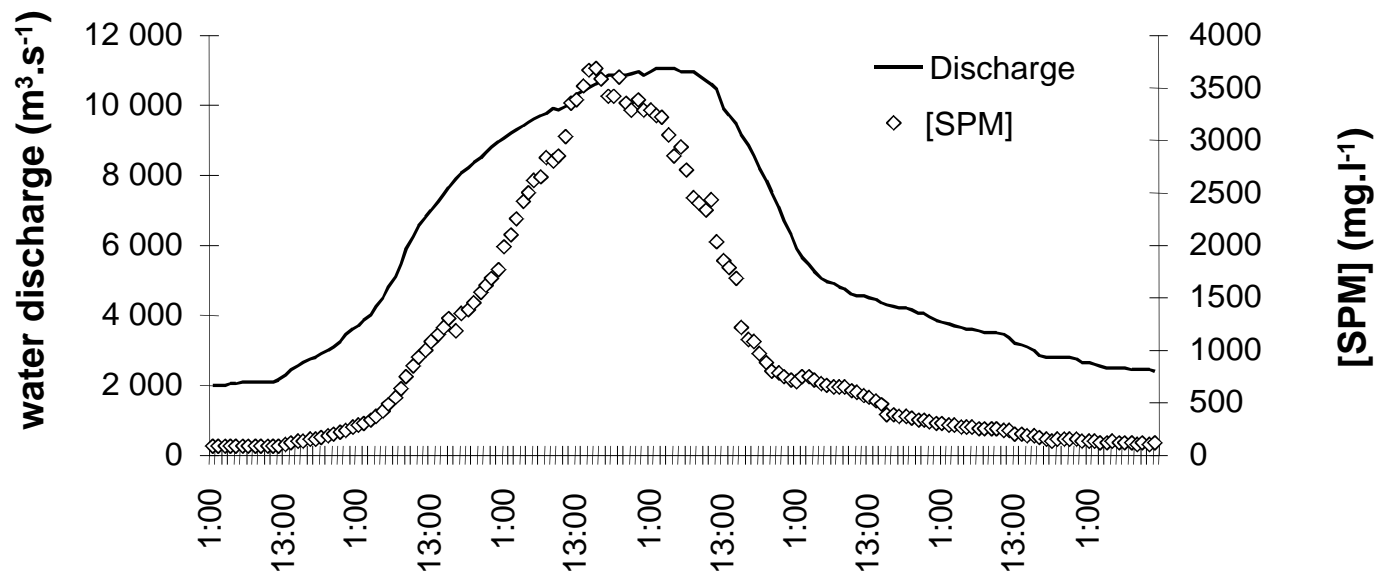

Hours

Figure 2: Miralles et al. 


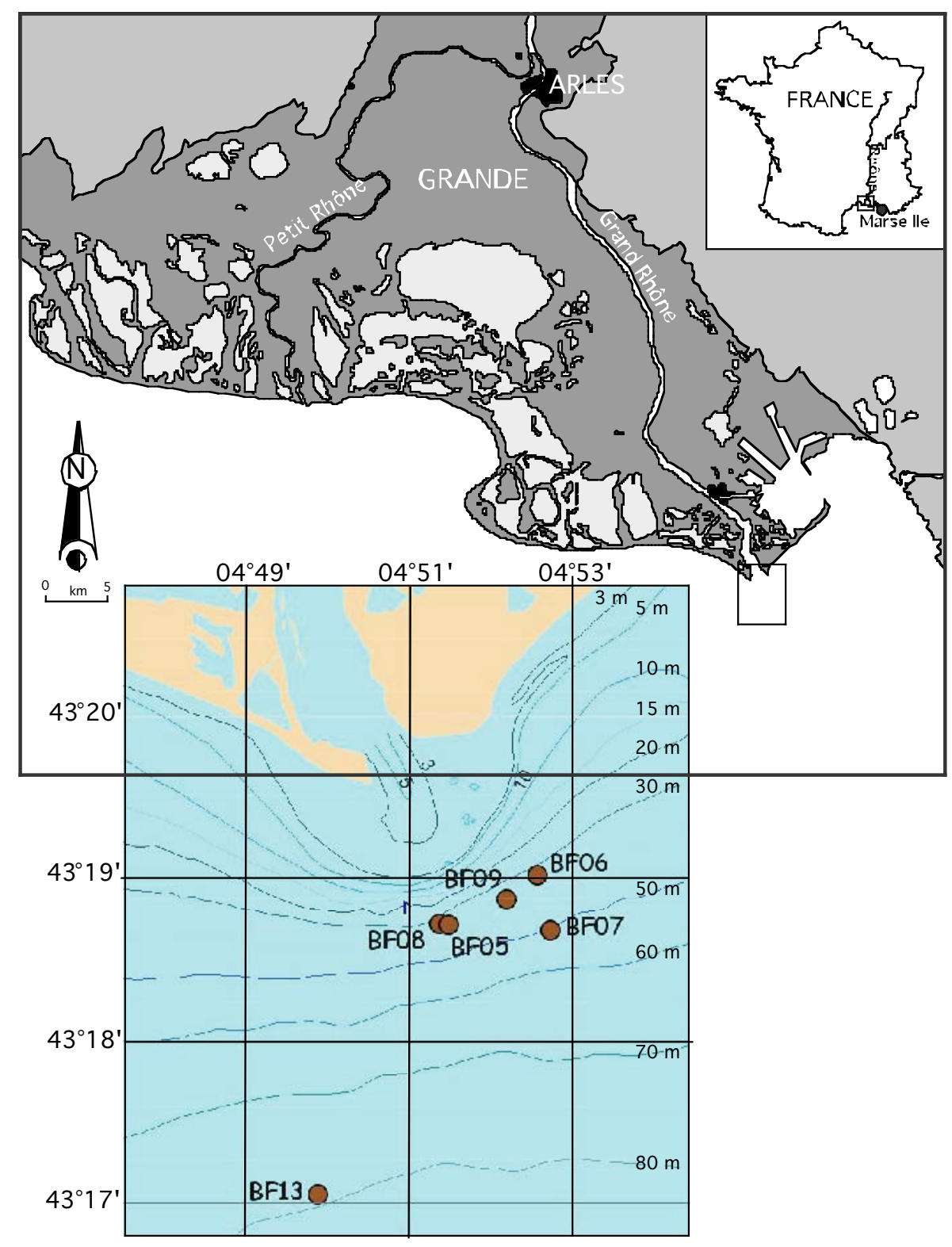

Figure 3: Miralles et al. 


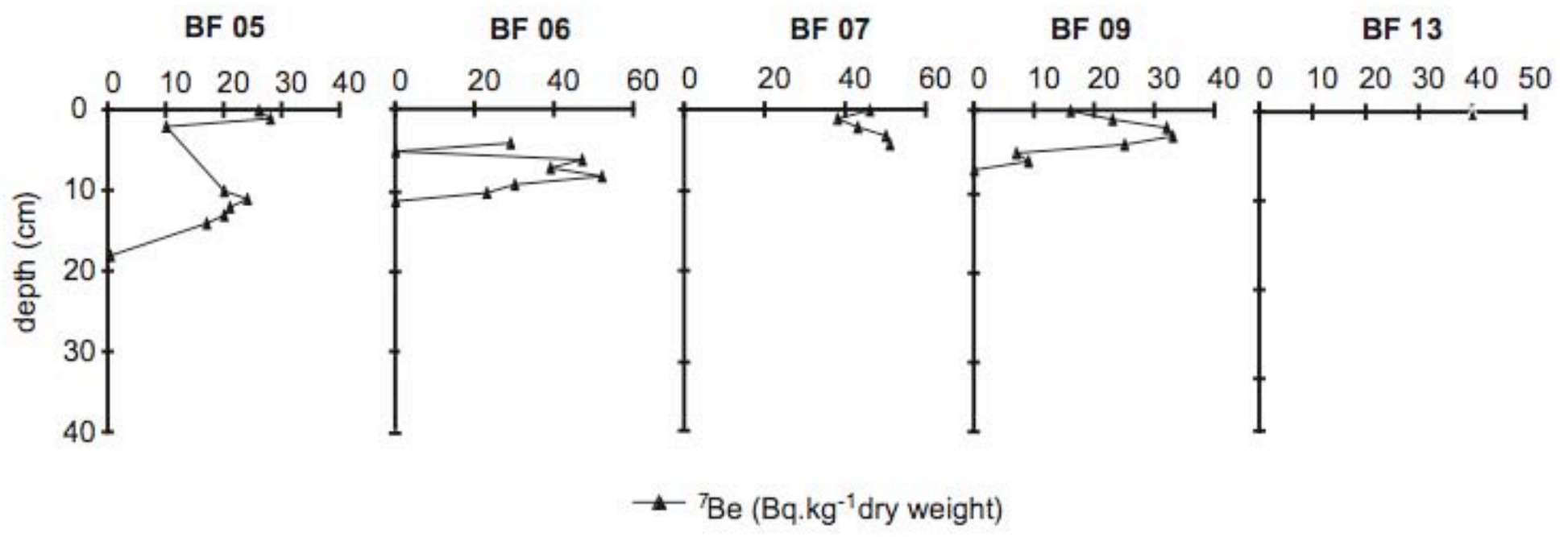

Figure 4: Miralles et al. 


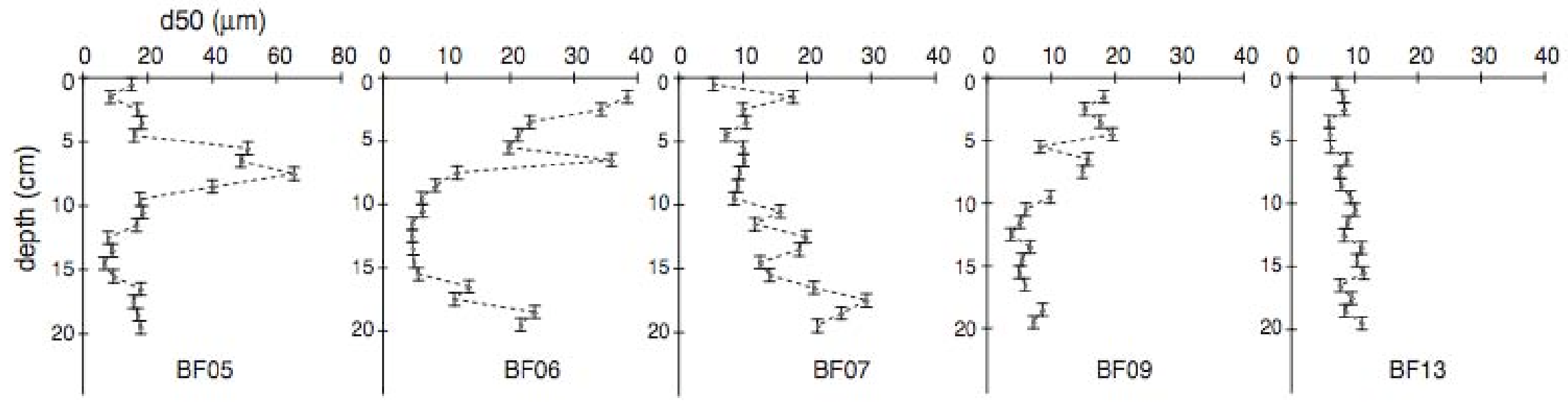

Figure 5: Miralles et al. 


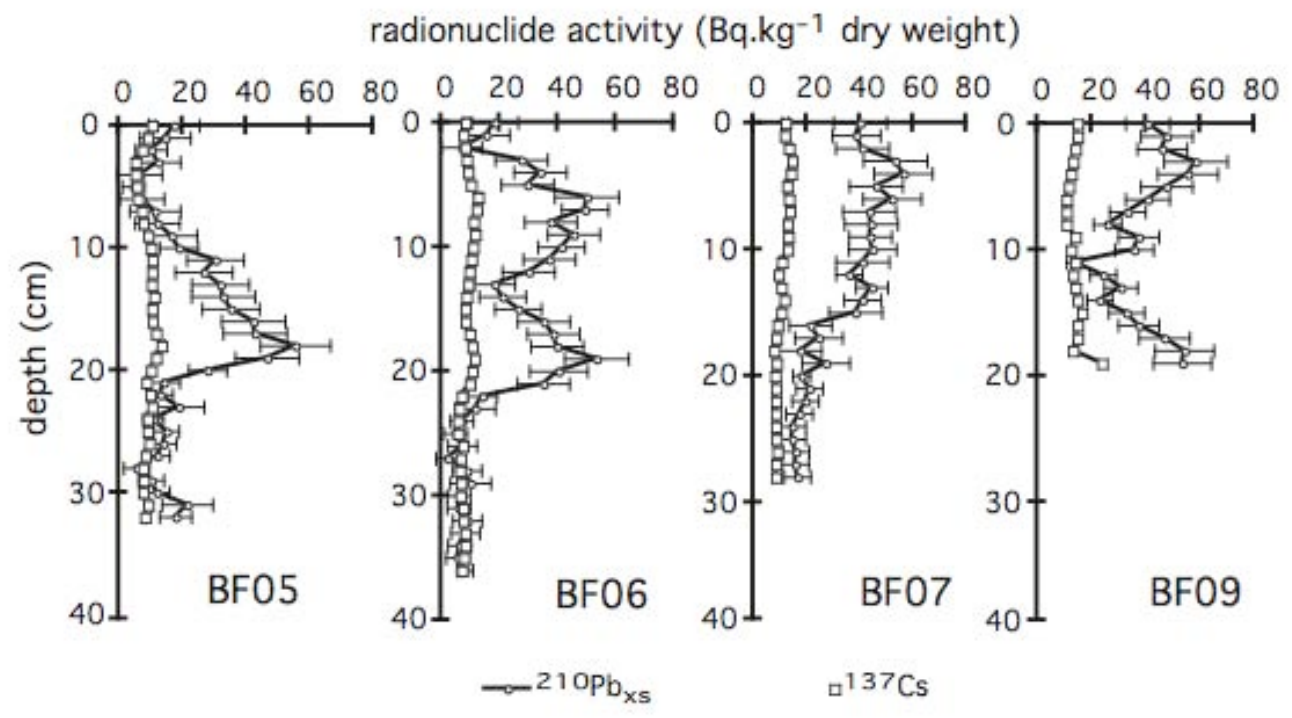

Figure 6: Miralles et al.

radionculide activity (Bq. $\mathrm{kg}^{-1} \mathrm{dry}$ weight)
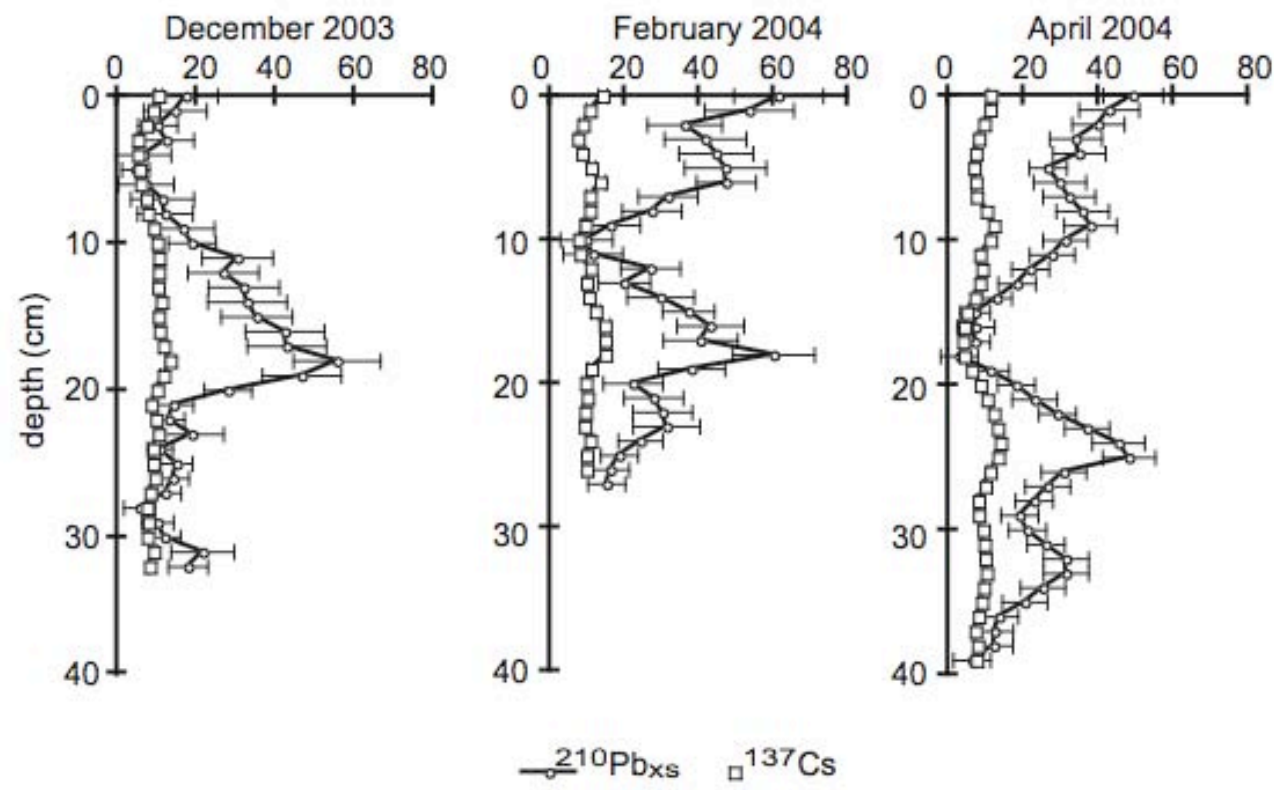

Figure 7: Miralles et al. 
Table 1: Sampling site locations at the Rhône River Mouth (WGS 84 reference plot).

\begin{tabular}{llccc}
\cline { 2 - 5 } & longitude & latitude & Depth $(\mathrm{m})$ & Core length $(\mathrm{cm})$ \\
\hline BF 05 & $04^{\circ} 51^{\prime} 197$ & $43^{\circ} 19^{\prime} 696$ & 28 & 33 \\
BF 06 & $04^{\circ} 52^{\prime} 015$ & $43^{\circ} 19^{\prime} 007$ & 27 & 37 \\
BF 07 & $04^{\circ} 52^{\prime} 118$ & $43^{\circ} 18^{\prime} 636$ & 45 & 29 \\
BF 08 & $04^{\circ} 51^{\prime} 116$ & $43^{\circ} 18^{\prime} 704$ & 26 & 36 \\
BF 09 & $04^{\circ} 51^{\prime} 732$ & $43^{\circ} 18^{\prime} 855$ & 29 & 39 \\
BF 13 & $04^{\circ} 49^{\prime} 940$ & $43^{\circ} 16^{\prime} 941$ & 79 & 39 \\
\hline
\end{tabular}

Table 2: ${ }^{\mathrm{Be}}$ (Bq.kg-1 dry weight) limit depth of detection in sediments.

\begin{tabular}{ccc}
\cline { 2 - 3 } & $\begin{array}{c}\text { TBe limit } \\
\text { of }\end{array}$ & $\begin{array}{c}\text { Water depth } \\
\text { of }\end{array}$ \\
& detection depth $(\mathrm{cm})$ & collection $(\mathrm{m})$ \\
\hline BF 05 & 27 & 28 \\
BF 06 & 11 & 27 \\
BF 07 & 5 & 45 \\
BF 08 & Not detected & 26 \\
BF 09 & 9 & 29 \\
BF 13 & 1 & 79 \\
\hline
\end{tabular}


Table 3: Medium diameter ( $\mathrm{d} 50$ expressed in $\mu \mathrm{m}$ ) baselines of the prodelta sediment cores.

\begin{tabular}{cc}
\cline { 2 - 2 } & $\mathrm{d} 50$ baseline $(\mu \mathrm{m})$ \\
\hline $\mathrm{BF} 05$ & $14 \pm 4$ \\
$\mathrm{BF} 06$ & $7 \pm 3$ \\
$\mathrm{BF07}$ & $9 \pm 1$ \\
$\mathrm{BF} 09$ & $6 \pm 2$ \\
$\mathrm{BF} 13$ & $9 \pm 2$ \\
\hline
\end{tabular}

Table 4: ${ }^{137} \mathrm{Cs}$ and ${ }^{210} \mathrm{~Pb}_{\mathrm{xs}}$ inventories deposited by December 2003 flood.

\begin{tabular}{|c|c|c|c|}
\hline & $\begin{array}{c}\text { sediment layer } \\
\text { (cm) }\end{array}$ & $\begin{array}{c}{ }^{210} \mathrm{~Pb}_{\mathrm{xs}} \text { inventory } \\
\left(\text { Bq. } \mathrm{m}^{-2}\right)\end{array}$ & $\begin{array}{c}{ }^{137} \text { Cs inventory } \\
\text { (Bq.m-2) }\end{array}$ \\
\hline \multirow{2}{*}{ BF 05} & 18 to 5 & Low: $3925 \pm 344$ & Low: $1372 \pm 35$ \\
\hline & 18 to surface & High: $4625 \pm 393$ & High: $1890 \pm 40$ \\
\hline \multirow{2}{*}{ BF 06} & 6 to 2 & Low: $1370 \pm 192$ & Low: $462 \pm 19$ \\
\hline & 6 to surface & High: $1764 \pm 232$ & High: $647 \pm 19$ \\
\hline BF 07 & 4 to surface & $1712 \pm 176$ & $494 \pm 19$ \\
\hline $\mathrm{BF} 09$ & 3 to surface & 1668 & 501 \\
\hline
\end{tabular}


Table 5: Flood deposition in cores collected at site BF05 in December 2003, February 2004 and April 2004.

December $2003 \quad$ February $2004 \quad$ April 2004

\begin{tabular}{cccc}
\hline${ }^{210} \mathrm{~Pb}_{\mathrm{xs}}$ inventory & Low: $3925 \pm 344$ & Low: $2721 \pm 264$ & Low: $1845 \pm 158$ \\
$\left(\mathrm{~Bq} \cdot \mathrm{m}^{-2}\right)$ & High: $4625 \pm 393$ & High: $4024 \pm 318$ & High: $3949 \pm 233$ \\
\hline Average \pm sd & $4275 \pm 495$ & $3373 \pm 921$ & $2897 \pm 1488$
\end{tabular}

\begin{tabular}{cccc}
\hline${ }^{137}$ Cs inventory & Low: $1372 \pm 35$ & Low: $1041 \pm 31$ & Low: $738 \pm 17$ \\
$\left(\right.$ Bq.m $\left.{ }^{-2}\right)$ & High: $1890 \pm 40$ & High: $1523 \pm 38$ & High: $1482 \pm 24$ \\
\hline Average \pm sd & $1631 \pm 366$ & $1282 \pm 341$ & $1110 \pm 526$
\end{tabular}

Table 6: ${ }^{137} \mathrm{Cs}$ and ${ }^{210} \mathrm{~Pb}_{\mathrm{xs}}$ deposition at site BF05 in response to the J anuary 2004 water discharge rise.

\begin{tabular}{|c|c|c|}
\hline & February 2004 & April 2004 \\
\hline \multirow{2}{*}{${ }^{210} \mathrm{~Pb}_{\mathrm{xs}}$ inventory $\left(\mathrm{Bq} \cdot \mathrm{m}^{-2}\right.$ ) } & Low: $1871 \pm 193$ & Low: $1283 \pm 113$ \\
\hline & High: $2880 \pm 245$ & High: $3030 \pm 186$ \\
\hline Average \pm sd & $2375 \pm 713$ & $2156 \pm 1235$ \\
\hline \multirow{2}{*}{ 137Cs inventory (Bq.m-2) } & Low: $429 \pm 19$ & Low: $335 \pm 10$ \\
\hline & High: $646 \pm 24$ & High: $756 \pm 16$ \\
\hline Average \pm sd & $537 \pm 153$ & $545 \pm 298$ \\
\hline
\end{tabular}

